EESTI NSV TEADUSTE AKADEEMIA TOIMETISED 195.5. IV kd., nr. 2 ИЗВЕСТИЯ АКАДЕМИИ НАУК ЭСТОНСКОЙ ССР 1955. Том IV, № 2

\title{
MIKS ON LOUUNA-EESTI MURDES lapse ASEMEL lats?
}

\section{P. ARISTE, \\ Eesti NSV Teaduste Akadeemia tegevliige}

Põhja-eesti ja louna-eesti murde juured ulatuvad õige kaugesse minevikku. Nagu osutavad keeleandmed, on lõuna-eesti ja põhja-eesti hõimukeel kujunenud iseseisvaks umbes samal ajal kui liivi, karjala ja vepsa hõimukeel. Mitmed louna-eesti erijooned on tekkinud juba enne meie ajaarvamist. Põhjapoolseks lõuna-eesti keelepiiriks on olnud umbes praegune lõunaja põhja-eesti murdepiir, lõunas on aga lõuna-eesti hõimu- ja hiljemini rahvakeel ulatunud palju kaugemale tänapäevasest eesti-läti keelepiirist. Veel meie aastatuhande alguses muinasläti Taalava ja Adzele maakonnas elanud louna-eestlaste viimased jääned on nn. leivud Ape (Нора) ja Lejasciemsi (Alamõisa) vahelisel maa-alal. XII sajandi vene kroonikais on otseselt mainitud, et Adzeles, vene keeli Очела, elab чудь, s. о. eestlased: „, а на зиму Мьстиславъ съ новгородьци на Чюдь, на̊ Очелу” ' 1 . Lõuna-eesti hõimurühm on hiljemini järk-järgult lähenenud põhja-eesti hõimurühmale. Mõlemad hõimurühmad on saanud eesti rahva ning eesti rahvuse aluseks. Endine lõuna-eesti hõimukeel on lähenenud ning läheneb veel praegugi põhja-eesti keelele, kuni ta viimasega lõplikult liitub. Kauges minevikus toimunud diferentsiatsiooniprotsess on ammu lakanud ja maad on vôtnud integratsiooniprotsess, mis on muutunud eriti tõhusaks pärast seda, kui kujunes eesti rahvus ning ühine eesti rahvuskeel.

Et lõuna-eesti murre on olnud endine vana läänemeré hõimukeel, seda osutavad selle murde sõnavara, grammatiline ehitus ja õige mitmed vanad foneetilised arengud. Lõuna-eesti murde sõnavara põhifondis on ohtrasti sõnu, mis pole omased teistele läänemere keeltele ega murretele, nagu anum 'nõu, riist', hõõlas 'vagu', kesv 'oder', kähr 'mäger', man 'juures', mõskma 'pesema', ruhim 'kamal', siug 'uss', tsuug 'pastel', ubin 'õun' jne. Tüüpiliselt lõuna-eestilistest morfoloogilistest erijoontest mainitagu kas või kolmanda pöörde lõppu (parandass 'parandab') ja seesütleva lõppu (suurõhn, suurõh, suurõn 'suures'). Lõuna-eesti hõimukeeles toimunud vanu foneetilisi arenguid, mida ei tunne teised läänemere keeled, on näiteks algupärase soomeugri $k t$ muutumine $t t$-ks ka pearõhulise silbi järel; teistes läänemere keeltes ja murretes on see sulghäälikute ühend arenenud $h t$-ks: lóuna-eesti vatt, põhja-eesti vaht, soome vaahto, karjala voahti, vepsa vaht jne.

1 Новгородская первая летопись старшего и младшего изводов, М.-Л., 1950; $1 \mathrm{k} 36$; Х. А. Моора, Этногенез народов Прибалтики по данным археологии, Краткие сообшения Инстнтута этнографии АН CССР, XII, M., 1950, lk. 36 jj. 
Lõuna-eesti murre läheb foneetiliselt ka selle poolest kõigist teistest läänemere. keeltest ja murretest lahku, et seal esineb lats 'laps', kütse 'küps', kütsetämä 'küpsetama' afrikaadi ts-ga kõigi teiste läänemere keelte ps-i asemel. Omapärase arenguga on ka lõuna-eesti sōna nüsmä 'lüpsma', nüssän 'lüpsan', mille vastetes teistes läänemere keeltes on samuti ps. Toodagu

selle kohta näiteid: vepsa raps' mitm. rapsed, küps, küpseda 'küpseda'! l'üps, l'üpsand 'lüps', l'üpsta l'üpstä ${ }^{2}$; karjala rapši. rapsi, küpši $\sim$ küpsi, lüpšän lüpsän ${ }^{3}$; isuri laps, küpsi, lüpsä 'lüpsta' 4; soome lapsi, kypsi,

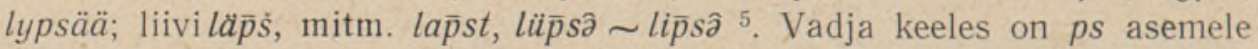
usutavasti fs vahendusel arenenud hs: rahsi 'laps', tšühsi 'küps', lühsä 'lüpsta' ${ }^{6}$.

Käsitledes läänemere keelte sõnasisest $p s$-ühendit, on E. N. S e t ä 1 ä üksnes konstateerinud, et teiste läänemere keelte $p s$-le vastab lõuna-eesti murde mainitud sõnades kas $t s$ või $s$, toomata ise mingit seletust selle omapärase nähtuse kohta ${ }^{7}$. L. K e $t \mathrm{t} u$ n e $n$ on arvanud oma eesti keele häälikuloos, et Iouna-eesti sõnas nüsmä olevat toimunud $p$ assimileerumine $s$-ga, ent teistes sõnades olevat $p s$-ühend arenenud $t s$-ks. Algselt olevat muutus toimunud üksnes $i$ ees (seega lapsi $>$ latsi) ning hiljemini olevat see levinud mujalegi. Et lõuna-eesti murdes on siiski ka selliseid sõnu, kus esineb konsonantide ühend ps (saps, om. sapso, pops jne.), siis on L. K e t t u n e n arvanud, et sellised sõnad on Iõuna-eesti murdesse teistest läänemere keeltest või murretest laenatud alles pärast seda, kui $p s$ muutumine $t s$-ks oli juba toimunud. Sama autori arvates on mõni lõuna-eesti ps-line sõna võimalik ka śelle tõttu, et asjaomane sõna on onomatopoeetiline või deskriptiivne (räpsä 'löön, virutan'), sest sellised sonnad võivat areneda muust sõnavarast häälikuliselt erinevat teed ${ }^{8}$. Toetudes $L$. Kettun enile ongi jäädud oletusele, nagu oleks lõuna-eesti murdes ps võinud areneda ts-ks. Niisugune häälikute arenemiskäik on aga foneetika seisukohalt arusaamatu, sest sulghäälikute $p$ ja $t$ artikulatsioonisuhted on üksteisest sedavõrd erinevad, et järkjärguliste nihete kaudu toimuv ühe hääliku asendumine teisega pole siin mõeldav. Võimatu on ka oletada, et mitmes sõnas oleks meelevaldselt hakatud $p s$-ühendi asemel tarvitama $t s$-ühendit. Sellepärast tuleb otsida teisi võimalusi lõuna-eesti lats-tüüpi sõnade foneetilise arenemise selgitamiseks.

On usutav, et kõnesolevates sõnades pole läänemere aluskeeles olnud ühend $p s$, vaid on esinenud ühend $p t s\left(<p t^{\prime} s^{\prime}\right)$, mis eri murretes on arenenud eri teed. Niihästi pōhja-eesti laps ning ps-lised vasted teistes sugulaskeeltes kui ka Iõuna-eesti lats näivad põlvnevat endisest lähtekujust *laptse. Nagu üldiselt läänemere aluskeeles, on selleski sõnas vana soomeugri $t \dot{s}$ ja $t s$ arenenud $s$-ks ${ }^{9}$. Seega muutus käesolev vana sõnatüvi "laptsehiljemini lapse-kujuliseks. Samuti on omaaegne tüvi *küptse-muutunud

2 E. A. T u n k e l o, Vepsän kielen äännehistoria, Helsinki, 1946, lk. 107; M. M. H ä mäläinen-F. A. A n drejev, Vepsa-venähine vajehnik, Moskva-Leningrad 1936; L. K ett u n e n, Lõunavepsa häälikajalugu I, Tartu, 1922, Ik. 37.

3 H. O ja n s u u, Karjala-aumuksen äännehistoria, Helsinki, 1918, 1k. 12 jj.

4 A. S ovi j ä r v i, Foneettis-äännehisteriallinen tutkimus Soikkolan inkeroismurteesta, Helsinki, 1944, lk. 45.

5 L. P o st i, Grundzüge der livischen Lautgeschichte, Helsinki, 1942, 1k. 234 jj.

6 L. Kettune n, Vatjan kielen äännehistoria. Toinen uusittu painos, Helsinki, 1930, 1k. 43.

7 E. N. Setäla, Yhteissuomalainen äännehistoria, Helsinki, 1891, Ik. 195 jj.

8 L. Kettune n, Eestin kielen äännehistoria. Toinen uusittu painos, Helsinki, 1929, lk. $42 \mathrm{jj}$.

9 Finnisch-ugrische Forschungen XXXI, Helsinki, 1953, Ik. 18 jj. 
hiljemini kujuks küpse-. Selles läänemere aluskeele murdes, millest on hiljemini arenenud lõuna-eesti hõimukeel, oli aga enne mainitud häälikumuutuse arenemist ühend $p t s$ arenenud $t t s-\mathrm{ks}$. Seega siis arenesid vanad läänemere *laptse- ja *küptse- tolles murdes kujudeks *lattse ja *küttse-, millest edasi kujunesid latse- ja kütse-. Et kõnesolevates sõnades on võinud tõesti olla $p+$ afrikaat, seda aitavad tõestada mordva keeled. Lõunaeesti sōnale nüsmä 'lüpsma', nüssä 'lüpsan' (on olemas muidki vanu läänemere sõnu, kus $l$ ja $n$ sõna alguses vahelduvad) leidub otseseid vasteid mordva keeltest: ersa ловцо, ловсо 'piim', чапамо ловцо 'hapu piim', mokša лофиа 'piim', лофциямс 'piima tulema, lüpsma hakkama'.

Seega on kõigiti tõenäoline, et ka läänemere hilisem tüvi lüpsä- on algselt olnud *lüptsä-. Uldiselt on läänemere aluskeeles selleski sõnas pts $>p s$. Lôuna-eesti keeles on aga pts $>t t s$; seega siis *nüptsä- $>*^{*} n \ddot{t} t s a ̈-$. Et tänapäeval on lõuna-eesti murdes siiski nüsmä ega ole *nütsmä, seletub $s$-lise ehk konsonanttüve üldistumisega neist juhtudest, kus $t s$ on seaduspäraselt muutunud $s$-ks, nimelt silbi lõpul konsonandi ees. Infinitiiv *nütstäk on pidanud arenema kujuks *nüstäk >nüstä 'lüpsta', partitsiip *nütsnük > *nüsnük $>$ *nüsnü jne. (vrd. louna-eesti väits 'nuga', aga osastav väist < *väitstä). Ootuspärane paradigma oleks lõuna-eesti murdes nüstä 'lüpsta' : *nütsä 'lüpsan' : nüsnü 'lüpsnud'. Et aga selline verbiparadigma on liiga keeruliste häälikuliste suhetega, on süsteemisunni tôttu toimunud paradigma lihtsustumine ja $s$ on saanud üldiseks kogu sõnatüves.

Mordva keeltes leidub vasteid ka läänemere lapse-tüvele: ersa левкс 'poeg (loomadest ja lindudest kõneldes)', верьгиз левкс 'hundikutsikas', реве левкс 'tall', нармунь левкс 'linnupoeg' левксылмс 'poegima'; mokša лефкс 'роеg', ката лефкс 'kassipoeg', пине лефкс 'koerapoeg'. Mordva keeles ei näe praegu küll afrikaati ts tuletusliite $k s$ ees, kuid võib siiski arvata, et siin on kunagi afrikaat olnud. Afrikaadi $t s$ kadu tuletusliite $k s$ ees on mordva keeltes üsna ootuspärane nähtus. Nõnda eesti sõnale väits, soome veitsi 'nuga', vastab ersa uнкc, mokša uнкc, ent murdeti ka intsks 'voolmed, voolimisnuga'; eesti vananenud sõnale ats, mis tuleb esile liitsõnas atspool 'süstik', vastab mokša aнкc 'kude'; soome sõnale jousi, joutsi 'amb, vibu' vastab ersa ja mokša ëнкс 'amb, vibu'. Seega siis ei kõnele mordva sõnad левкс ja лефкс omaaegse afrikaadi $t^{\prime} s$ või $t s$ olemasolu vastu ka läänemere lapse-tüve mordva vastetes.

Et ülalmainitud sõnades on olnud ühend $p t s$, seda aitab tõestada ka see seik, et algupärane $p s$-ühend on lôuna-eestigi murdes alal. Vanu $p s$-lisi sõnu on näiteks saps, kops. Pole mingit alust oletamiseks, nagu oleksid need sõnad laenatud põhja-eesti murdest.

Saabus toimetusse 24. III 1955

\title{
ПОЧЕМУ В ЮЖНОЭСТОНСКОМ ДИАЛЕКТЕ ВМЕСТО laps «ребенок» УПОТРЕБЛЯЕТСЯ lats?
}

\author{
П. А. АРИСТЭ,
}

действительный член Академии наук Эстонской ССР

Резюме

Южноэстонский диалект является очень древним. Он был одним из племенных языков прибалтийских финнов. В основной словарный фонд южноэстонского диалекта входит целый ряд слов, свойственных только этому диалекту. Южноэстонскому диалекту прнсущи также свои морфо- 
логические особенности и свои древние фонетические изменения, неизвестные другим прибалтийско-финским языкам. Одной из древних фонетических особенностей южноэстонского диалекта является наличие $t s$ или $s$ в словах lats 'ребенок', kütse 'спелый, зрелый, созревший', nüsmä 'доить, доиться' (ср. североэстонские laps, küps, lüpsma, финские lapsi, kypsi, lypsää и т. д.). В традиционных исторических фонетиках эстонского языка предполагается переход $p s$ в $t s$ или в $s$ в южноэстонском диалекте.

В приведенных словах первоначально было сочетание звуков pts $\left(<p^{\prime} t^{\prime} s^{\prime}\right)$ : *laptse-*küptse- *lüptsä-. В этих словах, как правило, древнее $t s$ перешло в $s$. Таким образом, из *laptse- *küptse- *lüptsä- получились lapse-, küpse- и lüpsä-. В этом диалекте прибалтийско-финского языка-основы, который стал основой позднего южноэстонского племенного языка, еще до перехода $t s$ в $s$ произошла ассимиляция $p t^{\prime} s^{\prime}$ в $t^{\prime} t^{\prime} s^{\prime}$. Так образовались формы *lattse- *küttse-, к которым восходят современные южноэстонские lats и kütse. В южноэстонском слове *nüpt's'ä- произошел такой же переход $p t^{\prime} s^{\prime}$ в $t^{\prime} t^{\prime} s^{\prime}>t s$. В конце слога, как правило, аффриката $t s$ заменена согласным $s$ (инфинитив nüsmä, партицип пüsnü и т. д.). Из закономерных форм образовались и остальные формы парадигмы, вытеснив $t s$. Мордовские параллели показывают, что также и в мордовском языкеоснфве в приведенных словах была когда-то аффриката.

Древнее сочетание звуков $p s$ сохранилось в южноэстонском диалекте и до настоящего времени.

Поступила в редакцию 24 III 1955 